\title{
Teacher's Role as An Information Gatherer: A Hidden Part in Developing Learning in Context
}

\author{
Absharini Kardena \\ English Education Department \\ IAIN Bukittinggi \\ Bukittinggi, Indonesia \\ absharinikardena@yahoo.co.id
}

\begin{abstract}
Teaching English cannot be generally taught in the same ways to different students who have different backgrounds. Each student may have different purposes, learning styles, needs, interest and so on that may affect their successful in learning English. Students' backgrounds may influence their comprehension in analyzing such contexts in a real communication. In this case, English teachers are supposed to gather information related to their students' backgrounds. This information later can be used by the teachers to develop learning materials, teaching techniques, and so on. Shortly, it may help the teachers to give directions in conducting teaching and learning processes by considering the context the language used. Related to this case, at least, there are 4 main points that should be considered by the teachers in EFL class; students' needs, students' interest, students' behavior, and students' social background. This paper is discussed about teachers' performance as an information gatherer and its influence on teaching and learning processes in the classroom. This paper, which is derived and further developed based on the research done in 2013, was a kind of phenomenological research. The data of the research were qualitative data that were collected through observation and interview.
\end{abstract}

\section{Keywords- role; information; gatherer; learning; context}

\section{INTRODUCTION}

Issues in teaching English as a foreign language are commonly related to students' inability to communicate well. Since the focus of teaching English has changed into building communicative ability, the goal of teaching and learning processes is also directed for achieving an ability to communicate whether in oral or written communication. For achieving this goal, English teacher should work collaboratively with students. Both the teacher and the students have their own contributions in building students' communicative ability. It is a real thing that the students have a wide portion in deciding the success of their learning process since they are the main players of their learning. They are the ones who really know the importance of learning English; the ones who know well why they need to learn English; and also the ones who have a motivation to learn English. It gives a high portion for them in succeeding their learning process. However, it cannot be denied that the teacher also plays a big role in accommodating the students in learning English.

It is a fact that the teacher has a control in deciding students' learning materials, especially in Indonesia.
Although the government has released the general points of learning materials, the teacher is still the one who decides the learning materials given to the students. The teacher will be the one who chooses the books, the exercises, etc that can lead the students to achieve the goals of teaching and learning processes. In this case, the teacher should have lots of knowledge.

The discussion of the students' aims in learning English can be divided based on their intention or their department. One of the examples can be taken from students at senior high school. In Indonesia, at least there are three types of senior high school; SMA/senior high school, SMK/ vocational school, and MAN/ Islamic senior high school. Each of these schools has its own purposes in teaching English. Generally, the purposes can also be classified into ESP (English for Specific Purposes) and EAP (English for Academic Purposes). By considering the two purposes of teaching English, each type of the senior high schools has their own priority of the purposes they would like to achieve. The students at the vocational school, for instance, need ESP more than EAP because they need English for real use in their own specific departments, such as engineering, business, etc. While students at SMA or MAN focus on EAP since their English is used generally in a wide range of topics for discussion, especially such general topics of discussion.

Related to EAP, many English teachers are argued that learning materials for all students can be the same. In fact, the students at senior high school, such as SMA and MAN, are grouped into at least two departments; science and social. These two departments surely have their own topics of discussion. By considering this fact, the teachers are supposed to consider students' backgrounds in deciding the teaching and learning processes in the classroom. Furthermore, the teachers need to know the specific goal of learning English for students in different department. None of them will have the same backgrounds since they graduated from different junior high schools; have different level of ability, needs, interest, etc. By considering these factors, the teachers may choose the most appropriate teaching technique for the students, the appropriate materials, evaluation, and so on. Simply, it can be stated that teachers' knowledge of students' backgrounds give the teachers some information in building a conducive atmosphere for students' learning. Building a conducive 
atmosphere for learning process is an important point. It is in line to the research finding conducted by [2] in which he found that learning environment contributes to students' achievement. In his research, the teacher as an object of the research plays a key role in building up a positive learning environment. The teaching technique used by the teacher influenced the classroom activities applied. Besides, the research also proved that teacher's approach influence students' motivation to learn. The teachers need to know the background and students' condition in such cases that may give significance progress for their learning achievement. In other words, the learning environment built by the teacher should consider the background of the students. These factors may also help the teacher to develop learning in context. It is a chance for the teacher to introduce the students that using English will never be $100 \%$ the same to their native language. There will be some contexts that they should notice while using English. It is the reason why a teacher needs to know students' backgrounds in order to plan classroom activities. In other words, the teacher has a role as an information gatherer that obligates her to collect information about students' backgrounds.

This paper, which was derived from a research conducted in 2013 and further developed at the end of 2016, discusses teachers' role as an information gatherer. The research was conducted in MAN Kota Solok. This research focused to look for students' backgrounds related to their needs, interests, behaviors and social backgrounds. The research was aimed to analyze how the teachers did their roles for gathering this information.

\section{METHOD}

The research was a kind of qualitative research, in case of phenomenological research. This research was conducted in MAN kota solok, one of Islamic senior high school in West Sumatra province, Indonesia. The research was conducted by involving all English teachers (5 English teachers) and students in 15 classes. Data of the research were collected through observation and interview. The classes were observed to see how the teachers played their role in the classroom. Besides, the teachers were also interviewed to get the data of their role as information gatherer. In addition, the students were also interviewed in order to verify the data gotten from the teachers and the observations. The data then were analyzed by following qualitative data analysis proposed by Patton.

\section{FINDING AND DISCUSSION}

Finding of the research showed that the teacher has a crucial part in building up a learning in context. It is started by their role as an information gatherer. The data on the field showed that 4 of 5 teachers did not gather information about students' background. The data of this point is stated table 1:
TABLE 1: Teachers' Performance As An Information Gatherer

\begin{tabular}{|c|c|c|c|c|c|c|c|c|c|c|c|c|c|c|c|c|c|c|c|c|c|c|c|c|c|c|c|c|c|}
\hline \multirow{4}{*}{$\begin{array}{l}\text { In } \\
\text { dic } \\
\text { ato } \\
\text { r }\end{array}$} & \multicolumn{29}{|c|}{ Participants' Code } \\
\hline & \multicolumn{5}{|c|}{$\mathrm{A}$} & \multicolumn{6}{|c|}{ B } & & \multicolumn{5}{|c|}{ C } & & \multicolumn{5}{|c|}{$\mathrm{D}$} & \multicolumn{6}{|c|}{$\mathrm{E}$} \\
\hline & \multicolumn{6}{|c|}{ Meeting } & \multicolumn{6}{|c|}{ Meeting } & \multicolumn{6}{|c|}{ Meeting } & \multicolumn{5}{|c|}{ Meeting } & \multicolumn{6}{|c|}{ Meeting } \\
\hline & 1 & 2 & $\begin{array}{lll}3 & \end{array}$ & & & & & & 3 & & & $\mathrm{~T}$ & & 2 & 3 & 4 & 5 & $\mathrm{~T}$ & 1 & 2 & \begin{tabular}{l|l}
3 & 4
\end{tabular} & $\begin{array}{l}75 \\
\end{array}$ & $\mathrm{~T}$ & 1 & 2 & 3 & 4 & 5 & $\mathrm{~T}$ \\
\hline $\mathrm{M}$ & - & - & - & & & & & & - & & & 0 & $v$ & - & $\mathrm{v}$ & $\mathrm{v}$ & - & 3 & - & - & \begin{tabular}{l|l}
- & -
\end{tabular} & - & 0 & - & - & - & - & - & 0 \\
\hline $\mathrm{N}$ & - & - & $\mathrm{v}$ & & & & & & - & . & & 0 & & $\mathrm{v}$ & - & - & - & 2 & - & - & $-1-$ & - & 0 & - & - & - & - & - & 0 \\
\hline $\mathrm{O}$ & $\mathrm{v}$ & $\mathrm{v}$ & $\mathrm{v}$ & & & & & & $\mathrm{v}$ & & $v$ & \begin{tabular}{|l|}
5 \\
\end{tabular} & $\begin{array}{l}\mathrm{V} \\
\mathrm{V}\end{array}$ & $\mathrm{v}$ & $\mathrm{v}$ & $\mathrm{v}$ & $\mathrm{v}$ & & $\mathrm{v}$ & $\mathrm{v}$ & \begin{tabular}{l|l}
$\mathrm{v}$ \\
$\mathrm{v}$
\end{tabular} & $\begin{array}{ll}\mathrm{V} & \mathrm{V}\end{array}$ & 5 & $\mathrm{v}$ & $\mathrm{v}$ & $\mathrm{v}$ & $\bar{v}$ & $\mathrm{v}$ & 5 \\
\hline $\mathrm{P}$ & $\mathrm{v}$ & $\mathrm{v}$ & $\mathrm{v}$ & & & & & & $\mathrm{v}$ & & $\mathrm{V}$ & 5 & $\begin{array}{lll} \\
\end{array}$ & $\mathrm{v}$ & $\mathrm{v}$ & $\mathrm{v}$ & $\mathrm{v}$ & & $\mathrm{v}$ & $\mathrm{v}$ & \begin{tabular}{l|l}
$\mathrm{v}$ \\
$\mathrm{v}$
\end{tabular} & \begin{tabular}{l|l}
$v$ &
\end{tabular} & 5 & $\mathrm{v}$ & $\mathrm{v}$ & $\mathrm{v}$ & $\mathrm{v}$ & $\mathrm{v}$ & 5 \\
\hline $\mathrm{T}$ & 2 & 2 & 3 & & & & & 2 & 2 & & 2 & & \begin{tabular}{l|l}
4 & 3
\end{tabular} & \begin{tabular}{|c|}
3 \\
\end{tabular} & \begin{tabular}{l|l}
3 &
\end{tabular} & 3 & 2 & & 2 & 2 & \begin{tabular}{l|l}
2 & 2
\end{tabular} & 22 & & 2 & \begin{tabular}{|l|l|} 
\\
\end{tabular} & 2 & 2 & 2 & \\
\hline
\end{tabular}

The data from table 1 show how the teacher performed their roles as an information gatherer. They were expected to collect information about students' need, students' interest, students' behavior, and students' social background. The information was important to guide the teacher in deciding and selecting any materials that were going to be used. In fact, the data on table 5 show that all English teachers always gathered any information about students' behavior and students' social background. However, there was only one teacher who tried to gather any information about students' need. Besides, it was also known that there were 2 from 5 English teachers who gathered information about students' interest.

Related to students' needs, the data from the observation also show that the other teachers never considered the students' need. One of the situations was when the teacher who taught at grade XII gave a text about rocket to students of religion department. This text absolutely did not relevant to students' department (religion). As a result, the students got confused of any technical terms since they only had limited knowledge of it. It proves how the teacher did not consider any topic that was related to the students' need. The data from the observation above were confirmed by the data from the interview.

Data interview 1:

$\mathrm{R}$ : hhhmmm... itu ibuk memilah materi yang akan diajarkan kepada anak, itu bagaimana caranya buk?

T: materi itu sebenarnya kan sudah ada dalam kurikulum ya, apa itu... garis besar yang akan diajarkan itu sudah ada. Guru tinggal mengikuti itu saja karena nantinya yang akan diuji kan materi yang ada dalam kurikulum. Kita sekarang pakai KTSP kan. Dalam KTSP kan memang garis besarnya saja.

R: kalau garis besarnya saja yang dimiliki guru, bagaimana ibuk menentukan materi khusus yang akan dibawa mengajar di kelas?

$\mathrm{T}$ : hhhmmm... ... itu kan bisa kita pilih saja ya... dari sumber-sumber yang ada.

R: berarti teks yang diberikan itu sama ya buk untuk semua lokal di kelas XII?

T: iya lah.

Translation of data interview 1:

$\mathrm{R}$ : hhhmmm... how do you decide teaching materials?

$\mathrm{T}$ : actually, the curriculum has provided the guideline for teaching materials. So, we just follow it because the final test will be about those materials. We use school-based curriculum now, and it provides the general guidelines.

$\mathrm{R}$ : so, how do you specify the specific materials based on those guidelines?

$\mathrm{T}$ : hhhmmmm ... we can choose it... from the available sources.

$\mathrm{R}$ : so, it means that the text for all students at grade XII is the same?

$\mathrm{T}$ : yes. 
The interview above proves that the teacher did not consider the students' need. It can be analyzed from teacher's statement in which she said that all the students in grade XII got the same text for each of genre. It means that the teacher did not consider the different department of the students. It explains why the teacher used the text about rocket to students in religion department. In other words, the teacher did not consider an appropriate material although the students were on different departments. In fact, the students in every department have different needs.

Based on the phenomenon above, 4 of 5 teachers did not consider students' needs. In fact, they chose the materials without considering students' needs. As a result, the materials that have been chosen were not always appropriate to students' needs. This fact was related to teachers' role as a decision maker. There was a link between students' need and the materials that were used. In other words, when the teachers did not collect any information about students' need, they have also failed in deciding the appropriate materials for the students because the materials provided did not always fulfill students' needs.

In a more detail discussion, the information related to students' need and students' interest influences teachers' decision in relation to learning materials [5]. It is relevant since this information is used as the basis to develop any learning materials. One important thing is the learners should learn something new, something interesting for them and the more important one is it should be something they need. By considering this statement, it is argued that teacher's role as an information gatherer is a kind of crucial role that should be applied by the teacher. In a more detail explanation, in positioning themselves as an information gatherer, the teachers should have such information related to students' background, such as students' need and interest. In other words, these needs and interests affect students' achievement as a whole, especially in comprehending learning English in a specific context [6].

In addition, as an information gatherer, the teachers were also demanded to collect any information about students' interest. Although the teachers should follow the general guideline from the curriculum, at least the teachers can give options for the students to choose the themes or topics that they like to discuss. The teachers can also give a chance to the students to select or design any classroom activities that can encourage students' motivation. However, in the realization, there were only 2 of the 5 English teachers who considered any topics or even the activities that the students liked. They showed it in different ways. One of them gave choices to the students to choose whether they wanted to continue the next materials/ lesson or to discuss the previous one deeply through doing more exercises. In addition, the teacher also performed a simple choice to decide whether the teacher or the students who take a first turn to read a text, whether the teacher modeled it first or the students read it directly by themselves. In other words, it could be stated that those teachers collected information about students' interest through giving them options in some moments during teaching and learning process.

In relation to students' interest in learning English, Asassfeh (2012) conducted a research related to students' preferences in learning English. The result of the research proved that the students had their own preferences on teaching and learning processes [1]. Generally, their preferences affected their performance in the classroom. Asassfeh stated that at least there were 4 aspects that influence students' preferences; gender effect, school type effect, grade level effect and proficiency level effect. In a more detail discussion, this research provided a choice for the students to choose between teaching technique that proposed communicative language ability as the main role, or traditional teaching technique. By looking at the 4 aspects influencing the students' preferences above, the research finding showed that the students had a high tendency to choose learning by applying communicative language teaching. This research convinces that students' interest can take a part in succeeding their achievement.

Moreover, the teachers were also supposed to collect any information about students' behavior. It included students' personality. Indeed, all the teachers showed a great performance in understanding students' behavior. The information that they collected was usually based on teacher's observation during teaching and learning processes. All the teachers can notice the students who commonly make a noise; the students who were more passive in learning process; and the students who were less motivated.

By using the information about their behavior, the teacher decided the strategy to face those students. The strategy depended on the case that was faced. If the students were noisy, the teacher asked them to keep silent. In another case, based on the observation, the teacher gave an extra task to the students who were noisy. Through those strategies, the teachers could handle the students by considering students' behavior. In other words, the information about students' behavior also influenced the way the teachers played their role as a counselor. It means that the teacher used the information about students' behavior as a basic consideration in choosing the right strategy and approach for each of the student. In other word, the teacher had different strategy and approach for different students based on their behavior in the classroom.

The last point of teachers' role as an information gatherer was collecting information about students' social background. The common way that was used by the teachers in gathering information about students' social background was through informal interview with the students and also by analyzing the information collected when the students registered on the school. It is supported by the data from the interview with the teachers. From the interview, the teachers stated that most of the students were categorized as middle or below economic classes. They knew it from the data on students' data when they registered 
as new students on the school. Besides, the teachers stated that they knew students' social background from informal interview in and out of classroom.

In this case, the teachers did really consider students' social background. One of the cases that can prove how far the teachers considered students' social background was on the moment when one of the students came late and the teacher let her joined the class. In fact, the teacher has known that the student was late because she had to walk to the school although there was a long distance between her house and the school. Teachers' consideration of this social background gave a positive atmosphere for the students. It could be seen that they did not face any pressure related to their capability in terms of economy, such as for buying a work-sheet, a textbook, etc.

This social background directly influences students' learning progress. A research done by Djigunovic (2012) found that at least there are 6 components that influence students' linguistics outcomes. It includes socioeconomic status, home support, outside school exposure (internet), motivation, linguistics self-confidence and learning environment [2]. All these aspects contribute to students' linguistics outcomes. Socio-economic status has a high relation to students' achievement since the way they interact each other influence their linguistic outcomes. The interaction here should be seen as a factor in which the students build a communication among peers. Moreover, home support is a kind of parents' support that would like to listen and watch the progress of their children in learning English. Based on the research, 855 parents show a high satisfaction and interest to see their children's' progress in learning English. By considering the finding of this research, it can be stated that students' socio economic class should be considered by the teacher in designing classroom activities since it relates to the context the students learn English as a foreign language. In other words, the teacher should consider students' environment and their social background in choosing any learning materials and media.

By looking at the phenomenon above, the teachers have tried to be an information-gatherer by collecting any information about students' interest, students' behavior, and students' social background. However, they still faced such difficulties in collecting any information that was related to students' need. In general, the teachers did not totally successful play their role as an information gatherer. As a result, it also influenced their role as a decision maker, especially in deciding the materials and classroom activity.

There were several causes of this problem. One of them was the material for teaching and learning process was taken only from the textbook or internet without any adaptation to students' need and students' real life. Besides, the decision making about the materials was only based on the curriculum that provides a general guideline. However, any information about students' need and students' interest were very crucial to the decision making of the materials [5]. It is strengthened by Kojima and Kojima (2005: 67-69) in which they say that any information that have been collected related to students' need, interest, behavior, and social background can be used for deciding and developing materials in teaching and learning processes [6]. The aim is to develop such materials that are appropriate to fulfill students' need in achieving the goal of teaching and learning. In other words, teachers' role as an information gatherer impacted to their role as a decision maker.

Based on the data analysis of the observation and interview, it was argued that they did not gather information about students' need because they only followed the guidelines on the curriculum. In other words, they did not consider students' need and students' interest when they decided the course design, such as teaching and learning goal, teaching materials, classroom activity, and so on.

Besides, the other finding of this research was the way the teachers run their roles as an information gatherer was influenced by the other role that was teachers' role as a reflective practitioner. Based on the data analysis, it can be concluded that those teachers did not gather information about students' need and students' interest because they did not evaluate their teaching process. It reflected that there was a link between teachers' role as an information gatherer and their role as a reflective practitioner. There was a cause and effect between these two roles. When the teacher did not reflect their teaching and learning processes, they also did not evaluate the fulfillment of students' need and students' interest during teaching and learning processes. When the teachers did not realize that students' need and students' interest were two important components that should be considered, they would never do their roles as an information gatherer. It proved the reason why there were only 1 teacher who collected information about students' need and students' interest and he was also the only one teacher who evaluated his teaching and learning processes.

The other finding of this research related to teacher's role as an information gatherer was the way the teachers played this role influenced the other role, which was their role as a decision maker. There was a cause and effect relationship between both of those roles. It could be analyzed from the phenomenon on this school in which the teachers who did not collect any information about students' need and students' interest have decided and set the teaching materials without considering students' need and students' interest. This phenomenon proved that there was an interrelated aspect between their roles as an information gatherer and their role as a decision maker.

As a conclusion, it can be stated that the teachers' role as an information gatherer involved some aspects. The teachers as an information gatherer has a link with their role as a reflective practitioner in which they were demanded to evaluate teaching and learning process by considering students' need and interest. Besides, the role as an information gatherer also influenced the way the teachers played their role as a decision maker, especially in deciding their teaching materials and classroom activity. In addition, it can also be concluded that the reason why the teachers did not collect information about students' need and students' 
interest was dealt to their comprehension of the curriculum that was applied. This situation leads to a bigger problem in which the teacher fails to build a system that offers students to learn in context. It is the reason why the students finally fail to achieve their goal of learning EFL. Since their goal is to have a good ability to communicate in English, they could not achieve it because they even do not interest more, or motivate to learn EFL yet. The students will not pay more attention to the lesson whenever the teacher also does not consider their needs and interest. Thus, it is important for the teacher to discuss and does such analysis of students' need and interest that may lead the teacher to build a learning in context which may improve students' motivation in EFL class.

\section{CONCLUSION AND RECOMMENDATION}

The success of implementing communicative language teaching, which focuses on developing students' communicative ability, depends on the collaboration of a teacher and students. The teacher cannot help the students without knowing deeply the background of the students. Any information about students' background may help the teachers to design the teaching and learning processes, such as developing the materials, choosing the appropriate teaching technique, choosing the appropriate media, and even deciding the evaluation system. It is the reason why the teacher is supposed to gather the information of students' background. It is one of the key points that are hidden so far in educational curriculum that finally affects the general process of teaching and learning activities. Therefore, the teachers are recommended to get involved in collecting the data of students' background in order to give them such considerations in deciding and conducting teaching activities. It is expected that those information may help the teacher to build up such learning in context. This kind of learning can be used as a key point to improve students' attention and motivation to learn EFL. It may also give such reasons for the students to understand the demand of using English and how to use it appropriately. It can be built up through the first step from the teacher; gathering information of students' background.

\section{References}

[1] S. Asassfeh, "Communictaive language teaching in EFL context: learners' attitudes and perceived implementation," Journal of Language Teaching and Research. Vol. 3, pp. 525-535, 2012.

[2] J. Djigunovic, "Early EFL learning in context- evidence from a country case study," ELT Research Papers. Vol.12, pp. 1-19, 2012.

[3] A. Kardena, "Problematic sides in implementing learner-centered instrcution paradigm in English classroom: a phenomenological study at MAN Kota Solok," Unpublished.

[4] A. Kardena, "Change of Curriculum and Its Implication on Teachers' Performance in EFL Classroom," in Proceedings of Third International Seminar on English Language and Teaching, Universitas Negeri Padang, 2015.
[5] A. Kilic, "Learner-centered micro teaching in teacher education," International Journal of Instruction, Vol 3, pp. 77-100, 2010.

[6] H. Kojima and Y. Kojima, "Teacher roles in learner-centered communictaive EFL instruction" in http://repository.ul.hirosaki u.ac.jp/dspace/bitstream/10129/ 544/1/AN00211590 94)59.PDF, 2005.

[7] S. Savignon and C. Wang, "Communictaive language teaching in EFL contexts: learners attitudes and perceptions," IRAL, Vol. 41, pp.223-249, 2003.

[8] H. Xu, "From EFL to ESL: the influence of context on learners' motivational profiles," Arizona Working Papers in SLA and Teaching, Vol. 17, pp. 123-142. 2010 